\title{
Development and characterization of thermosensitive pluronic-based metronidazole in situ gelling formulations for vaginal application
}

\author{
EL-SAYED ALI IBRAHIM ${ }^{1}$ \\ SAYED ISMAIL ${ }^{1}$ \\ GIHAN FETIH ${ }^{1 *}$ \\ OMAR SHAABAN ${ }^{2}$ \\ KHALED HASSANEIN ${ }^{3}$ \\ NOURA HASSAN ABDELLAH ${ }^{1}$ \\ 1 Department of Pharmaceutics, Faculty \\ of Pharmacy, Assiut University, Egypt \\ 2 Department of Obstetrics and Gynecology \\ Faculty of Medicine, Assiut University \\ Egypt \\ ${ }^{3}$ Department of Pathology and Clinical \\ Pathology, Faculty of Veterinary \\ Medicine, Assiut University, Egypt
}

\begin{abstract}
The purpose of this study was to develop pluronic-based in situ gelling formulations of metronidazole (MTZ) for treatment of bacterial vaginosis, aimed at prolonging the residence time, controlling drug release, enhancing efficacy, decreasing recurrence, and increasing patient compliance. The in situ gel formulations were prepared using different concentrations of pluronic F-127 (PF-127) alone and in combination with pluronic F-68 (PF-68). The prepared formulations were evaluated for their gelation temperature $\left(T_{\text {gel }}\right)$, in vitro drug release, rheological properties, mucoadhesion properties and tolerability by vaginal mucosa in tissue levels. The $T_{\text {gel }}$ decreased with increasing PF-127 concentration. The $T_{\text {gel }}$ was modulated by addition of PF-68 to be within the acceptable range of $25-37^{\circ} \mathrm{C}$. With increasing pluronic concentration, the in vitro drug release decreased, viscosity and mucoadhesive force increased. Histopathological examination of rabbit vaginas from the control and treated groups revealed normal histology of the vagina and cervix. Based on the in vitro evaluation of prepared formulations, the in situ gelling liquid formulated with PF-127/PF-68 (20/10 \%, $\mathrm{m} / \mathrm{m}$ ) was selected for further clinical evaluation.
\end{abstract}

Keywords: metronidazole, in situ gelling, mucoadhesion, pluronics

There are two challenges in vaginal drug delivery. First, the limited contact time caused by the physiological conditions imposed by the protective mechanisms of the vagina (resulting in a frequent dosing regimen). The second challenge is patient compliance. Conventional vaginal dosage forms such as ointments and inserts cause discomfort to the patients (1). Although it is known that patients tolerate gels better than inserts or ointments, direct application of gels into the vagina might be difficult as well as inconvenient (1). Recently, in situ gelling liquids have been investigated as a more convenient

\footnotetext{
* Correspondence; e-mail: gfetih@yahoo.com
} 
dosage form for topical applications. The in situ forming hydrogels are stimuli-sensitive hydrogels that exist as aqueous solutions before administration and immediately change into standing gels after administration upon contact with the mucosa. The most commonly used thermoreversible gels are pluronics (2). The pluronic-based in situ gelling dosage form is supposed to be easily applied and to give good spreading and coating of the vagina, making the treatment more effective and probably result in prolonged effect $(1,3)$.

Metronidazole (MTZ) was considered a drug of choice for treatment of bacterial vaginosis. Prolonged treatment was found to be the only effective solution to prevent the high recurrence rate; however, such approach raises concerns about potential toxicity.

The objective of this study was to design a new vaginal thermosensitive in situ gelling formulation with mucoadhesive properties.

\section{EXPERIMENTAL}

\section{Materials}

Metronidazole was generously donated by Nile Pharmaceuticals and Chemical Industries Co. (Egypt). Pluronic F-127, Pluronic F-68, mucin powder and benzalkonium chloride were purchased from Sigma Chemical Co. (USA). Sodium chloride, calcium hydroxide, potassium hydroxide, acetic acid, and glycerol were obtained from El-Nasr Company (Egypt). All the other chemicals were of pharmaceutical grade and were used as received. The marketed preparation Tricho® $0.75 \%$ (commercial MTZ vaginal gel) was purchased from Chemical Industries Development (CID) Co., Egypt.

\section{Preparation of pluronic gel formulations}

Different concentrations of Pluronic F-127 alone or in combination with Pluronic F-68 were used in the preparation of in situ gelling liquids. Medicated in situ gelling liquids were prepared on a mass basis using the modified cold method (4). Composition of the prepared formulations is shown in Table I. For formulations $\mathrm{F}_{1}$ to $\mathrm{F}_{8}$, Pluronic F-127 or combination of Pluronic F-127 and Pluronic F-68 were mixed and dissolved with $0.8 \%$ MTZ in cold citro-phosphate buffer of $\mathrm{pH}$ 4.5. Benzalkonium chloride, concentration 0.01 $\%$, was used as preservative. Partially dissolved pluronic solutions were stored in a refrigerator at $4{ }^{\circ} \mathrm{C}$ overnight and stirred periodically until clear homogenous solutions were obtained.

\section{Gelation temperature $\left(\mathrm{T}_{\text {gel }}\right)$ measurement}

Ten milliliters of cold sample solution (pluronic containing formula) were put into a beaker $(25 \mathrm{~mL})$ placed in a low temperature water bath at room temperature. A thermometer was immersed in the sample solution. The solution was heated at a constant rate of $200 \mathrm{rpm}$ under continuous stirring using a magnetic bar (Barnstead/Thermolyne, USA). The temperature at which the magnetic bar stopped moving due to gelation was reported as the gelation temperature $\left(T_{\text {gel }}\right)(5)$. Each sample was measured in triplicate. 


\section{Rheological studies}

Rheological studies of the samples were carried out using a DV-III Ultra viscometer, RV model, Brookfield, USA. Viscosity was measured at different temperatures of 4, 25 and $34{ }^{\circ} \mathrm{C}$. The viscosity of each sample was determined before and after gelifying. Each point is the mean of three readings.

\section{Mucoadhesive force determination}

Mucoadhesive forces of all the prepared formulations were determined using a mucoadhesive force measuring device, which is a modified balance. This balance was developed in our laboratory with slight modifications, according to the previously reported methods (6).

The mucoadhesive force of the formulations under examination was determined by measuring the force required to detach the formulation from a mucin disc using the measuring device. At the right arm of the balance, a mucin disc was horizontally glued to the lower surface of the right pan of the modified balance. The mucin disc was hydrated with distilled water prior to the mucoadhesion test. Three drops of each formula were placed on the upper surface of an inverted beaker, which was placed directly below the right pan. The in situ forming liquid sample was exposed to a source of heat to allow gelation. The upper stage of the modified balance containing the hydrated mucin disc was adjusted to be in contact with the preparation. A preload of 10 grams was immediately applied for 1 minute to ensure intimate contact between the mucin disc and the sample and to allow formation of an adhesive bond. The preload time and the force were kept constant for all the tested formulations. After completion of the preload time, water was allowed to drip from the infusion set into a preweighed plastic jar placed on the left pan of the balance at a constant rate of $5 \mathrm{~mL}$ per minute. The dripping of water was stopped when the mucin disc was detached from the tested sample, the filled plastic jar was reweighed and the mass of water required to detach the tested sample from the mucin disc was calculated from the difference (7).

Measurements were repeated three times for each of the gel preparations, but a fresh smooth gel surface was created before each measurement.

\section{In vitro release of MTZ from in situ gelling formulations}

In vitro release of MTZ from in situ gelling formulations was studied using a standard semi-permeable cellophane membrane. The release medium was a simulated vaginal fluid (SVF). Simulated vaginal fluid was prepared as described (8). The $\mathrm{pH}$ of the mixture was then adjusted to 4.5 using $\mathrm{HCl}$. The membrane was firmly stretched over one end of the glass tube $(2.4 \mathrm{~cm}$ internal diameter $)$ by means of a rubber band. One gram of the tested formulation solution was weighed over the membrane in the dialysis tube. The tube was suspended in a $250-\mathrm{mL}$ glass cup containing $100 \mathrm{~mL}$ freshly prepared release medium (SVF) (9). The experiment was carried out at constant temperature in a shaking water bath previously adjusted to $37 \pm 0.2{ }^{\circ} \mathrm{C}$ and 75 stroke per minute. Aliquots $(1 \mathrm{~mL})$ were withdrawn from the release medium at each sampling time for up to $6 \mathrm{~h}$ and $24 \mathrm{~h}$ in case of comparison with the marketed preparation. The aliquots were re- 
placed with an equal volume of the freshly prepared release medium kept at the same temperature. The aliquots were diluted, and the amount of drug released was calculated by measuring the absorbance at $320 \mathrm{~nm}$ against a blank (UV spectrophotometer, Jenway, UK). The results were the mean of three runs. The release profile of MTZ was obtained by plotting the \% cumulative amount of drug released from each formulation against time.

\section{Histopathological study of vaginal tissues}

Formula selection was done by screening all prepared formulations through the in vitro histopathological characterization (10) for their tolerability by vaginal tissues. The study obtained the approval from the Ethical Committee of the Faculty of Pharmacy, Assiut University. Five adult female rabbits (weighing 1.5-2 kg) were used. $\mathrm{F}_{7}$ mucoadhesive thermosensitive formulation was administered into the vagina $\left(1 \mathrm{~mL} \mathrm{~kg}^{-1}\right)$ for three consecutive days. At $6 \mathrm{~h}$ post last dose, specimens from vagina and cervix were isolated and fixed in $10 \%$ neutral buffer formalin, dehydrated in a graded alcohol series, cleared with methyl benzoate and embedded in paraffin wax. Four micron sections were cut and stained with haematoxylin and eosin (HE) for histopathological examination by light microscopy. Specimens from control rabbits (no gel administered to the vagina), were similarly treated for comparison.

\section{RESULTS AND DISCUSSION}

MTZ concentration in all formulations was $0.8 \% \mathrm{~m} / \mathrm{m}$ and that of pluronics varied 0-30 \% (Table I). Drug content uniformity of the prepared formulations ranged from 99.2 to $100.3 \%$ of the labeled amount.

\section{Gelation temperature $\left(\mathrm{T}_{\text {gel }}\right)$}

$T_{\text {gel }}$ is the temperature at which the liquid phase makes a transition to gel. An ideal in situ gel should be a free flowing liquid at room temperature so as to allow reproducible administration into the site of application where it undergoes in situ phase transition to form a strong gel (11). The human vaginal temperature is $37.2{ }^{\circ} \mathrm{C}(12)$, so $T_{\text {gel }}$ of vaginal thermoreversible gels were considered to be suitable if they were in the range of 25-37 ${ }^{\circ} \mathrm{C}$. If the $T_{\text {gel }}$ is lower than $25^{\circ} \mathrm{C}$, a gel might be formed at room temperature, leading to difficulties in manufacturing, handling, and administering. If $T_{\text {gel }}$ is higher than $37^{\circ} \mathrm{C}$, a liquid dosage form still exists at vaginal temperature, resulting in drainage of the formula from the vagina at an early stage.

The data in Table I show that PF-127 alone at concentrations of 15, 20, 25 and $30 \%$ $\left(\mathrm{F}_{1}-\mathrm{F}_{4}\right)$ gave $\mathrm{T}_{\text {gel }}$ higher than $40,22,18$ and $10{ }^{\circ} \mathrm{C}$, respectively. These gelation temperatures are not within the suitable range. An increase in PF-127 concentration resulted in a decrease in $T_{\text {gel }}$; this finding was in agreement with the data of Edsman et al. (13).

A modulation of $T_{\text {gel }}$ to reach the desired range was achieved by using a combination of the two pluronics (grades F-127 and F-68). 
E. S. A. Ibrahim et al:: Development and characterization of thermosensitive pluronic-based metronidazole in situ gelling formulations for vaginal application, Acta Pharm. 62 (2012) 59-70.

Table I. Composition of pluronic-based vaginal in situ gelling formulations of MTZ and their gelation temperatures

\begin{tabular}{cccc}
\hline \multirow{2}{*}{ Formula code } & \multicolumn{2}{c}{ Ingredient $(\%, m / m)^{\mathrm{a}, \mathrm{b}}$} & $T_{\text {gel }}\left({ }^{\circ} \mathrm{C}\right)^{\mathrm{c}}$ \\
\cline { 2 - 3 } & PF-127 & PF-68 & $>40$ \\
\hline $\mathrm{F}_{1}$ & 15 & - & $22 \pm 0$ \\
$\mathrm{~F}_{2}$ & 20 & - & $18 \pm 1$ \\
$\mathrm{~F}_{3}$ & 25 & - & $10 \pm 1$ \\
$\mathrm{~F}_{4}$ & 30 & - & $36 \pm 1$ \\
$\mathrm{~F}_{5}$ & 15 & 15 & $29 \pm 1$ \\
$\mathrm{~F}_{6}$ & 15 & 20 & $28 \pm 0$ \\
$\mathrm{~F}_{7}$ & 20 & 10 & $27 \pm 1$ \\
$\mathrm{~F}_{8}$ & 20 & 15 & \\
\hline
\end{tabular}

a Vehicle: citro-phosphate buffer $\mathrm{pH} 4.5$.

b MTZ content in all formulations $0.8 \%(\mathrm{~m} / \mathrm{m})$; content uniformity $99.2-100.3 \%$.

c Each value represents the mean \pm SD of three experiments.

Effect of PF-68 addition on $\mathrm{T}_{\text {gel }}$. - $T_{\text {gel }}$ for PF-127 solutions and the solutions of PF-127/PF-68 mixtures are shown in Table I. Formulations $\mathrm{F}_{5}-\mathrm{F}_{8}$ were found to gel between 25 and $37^{\circ} \mathrm{C}$, so they were considered to be suitable for vaginal application. Several combinations of the two polymeric grades were tested and used in the formulation of the in situ gelling liquids in order to select formulations having a suitable $T_{\text {gel }}$ (Table II). As shown in Tables I and II, the $T_{\text {gel }}$ changed with the addition of PF-68 to 15 and $20 \%$ PF-127. The results showed that at constant PF-127 concentration, increasing the PF-68 concentration gradually increased the $T_{\text {gel }}$ initially to a maximum, and then it decreased. Maximum concentration of PF-68 was $10 \% . T_{\text {gel }}$ decreased with further increment in PF-68 concentration. Similar results were previously reported (14).

Table II. Effect of PF-68 on gelation temperature

\begin{tabular}{cccc}
\hline \multicolumn{2}{c}{ PF-127 (15\%) } & \multicolumn{2}{c}{ PF-127 $(20 \%)$} \\
\hline PF-68 $(\%)$ & $T_{\text {gel }}\left({ }^{\circ} \mathrm{C}\right)^{\mathrm{a}}$ & PF-68 $(\%)$ & $T_{\text {gel }}\left({ }^{\circ} \mathrm{C}\right)^{\mathrm{a}}$ \\
\hline 0 & $>40$ & 0 & $22 \pm 0$ \\
3 & $>40$ & 3 & $25 \pm 0$ \\
6 & $>40$ & 6 & $27 \pm 1$ \\
10 & $>40$ & 10 & $28 \pm 0$ \\
15 & $36 \pm 1$ & 15 & $27 \pm 1$ \\
20 & $29 \pm 1$ & 20 & $22 \pm 1$ \\
\hline
\end{tabular}

\footnotetext{
a Each value represents the mean \pm SD of three experiments.
} 
It is known that when the concentration and temperature of the polymer are above a critical value, pluronic molecules in aqueous solution will self-assemble to form spherical micelles with a dehydrated polypropylene oxide (PPO) core surrounded by hydrated swollen polyethylene oxide (PEO) chains (15). The thermoreversible gelation behavior is accepted as a result of micellar entanglement and packing with the increase in temperature. Furthermore, it is generally accepted that the PPO, which is hydrophobic, has lowered $T_{\text {gel }}$ and the PEO, which is hydrophilic, has increased $T_{\text {gel }}$. Therefore, a different $\mathrm{PEO} / \mathrm{PPO}$ ratio will lead to a different $T_{\text {gel }}$. The ratio of PEO/PPO in PF-127 is 7:3, while in PF-68 it is 8:2. Thus, when a slight amount of PF-68 is added to a PF-127 solution, the proportion of PEO increases, which leads to an increase in $T_{\text {gel }}(11,14)$. The possible reason for $T_{\text {gel }}$ decrease after a certain concentration of PF-68 (10\%) is that the incorporation of a small amount of PF-68 can only change the PEO/PPO ratio, causing an increase in $T_{\text {gel }}$, while by increasing the PF-68 concentration sequentially, not only the PEO/PPO ratio changes, but also the micellization of PF-68 molecules can participate in the construction of the gel, which finally leads to a decrease in $T_{\text {gel }}(14)$.

\section{Rheological study}

Rheological behavior is the key part in the formulation of PF-127 preparations. Table III shows the viscosity of pluronic formulations at different PF-127 concentrations. The same concentration of pluronic has different viscosity at different temperatures (4, 25 , and $37^{\circ} \mathrm{C}$ ), where the viscosity increased with increasing temperature. This may be attributed to the fact that pluronics, being non-ionic PPO triblock copolymers, aggregate into micelles at $37{ }^{\circ} \mathrm{C}$. This micellization is due to the dehydration of polymer blocks with temperature. It has been shown that gel formation is a result of micellar enlargement and packing and that the gel is more entangled at higher PF-127 concentrations. As a result of these micelle entanglements, they cannot separate easily from each other, which accounts for the rigidity and high viscosity of gels containing high concentrations of pluronics $(15,16)$.

Table III. Viscosity and mucoadhesive force of pluronic formulations

\begin{tabular}{cccrc}
\hline \multirow{2}{*}{$\begin{array}{c}\text { Formula } \\
\text { code }\end{array}$} & \multicolumn{3}{c}{ Viscosity $(\mathrm{mPa}$ s) at temperature } & $\begin{array}{c}\text { Mean mucoadhesive } \\
\text { force } \times 10^{2}\left(\mathrm{~N} \mathrm{~cm}^{-2}\right)^{\mathrm{a}}\end{array}$ \\
\cline { 2 - 4 } & $4{ }^{\circ} \mathrm{C}$ & $25{ }^{\circ} \mathrm{C}$ & \multicolumn{1}{c}{$37^{\circ} \mathrm{C}$} & $-{ }^{\mathrm{b}}$ \\
$\mathrm{F}_{1}$ & 0.00 & 66.7 & $21.6 \times 10^{3}$ & $15.8 \pm 0.4$ \\
$\mathrm{~F}_{2}$ & $<100$ & $138.3 \times 10^{3}$ & $205.1 \times 10^{3}$ & $17.2 \pm 2.5$ \\
$\mathrm{~F}_{3}$ & 233 & $151.5 \times 10^{3}$ & $243 \times 10^{3}$ & $19.0 \pm 3.7$ \\
$\mathrm{~F}_{4}$ & 280 & $170 \times 10^{3}$ & $267.7 \times 10^{3}$ & $18.2 \pm 2.5$ \\
$\mathrm{~F}_{5}$ & 333.3 & 916.4 & $6.6 \times 10^{3}$ & $21.9 \pm 0.4$ \\
$\mathrm{~F}_{6}$ & 333 & $1.677 \times 10^{3}$ & $90.4 \times 10^{3}$ & $21.2 \pm 1.4$ \\
$\mathrm{~F}_{7}$ & 306 & 932 & $199.6 \times 10^{3}$ & $23.9 \pm 0.4$ \\
$\mathrm{~F}_{8}$ & 422 & $1.177 \times 10^{3}$ & $222.4 \times 10^{3}$ & \\
\hline
\end{tabular}

\footnotetext{
a Mean $\pm \mathrm{SD}, n=3$.

b Gelation temperature of $\mathrm{F}_{1}$ was $>40{ }^{\circ} \mathrm{C}$, so it could not be handled during mucoadhesive force determination (it liquefied during the experiment).
} 
E. S. A. Ibrahim et al.: Development and characterization of thermosensitive pluronic-based metronidazole in situ gelling formulations for vaginal application, Acta Pharm. 62 (2012) 59-70.

Effect of PF-68 addition on viscosity. - Table III shows the results for the viscosity of PF-127 formulations containing PF-68. Formulations composed of PF-127/PF-68 at concentrations 15/15 $(\%)\left(\mathrm{F}_{5}\right), 15 / 20(\%)\left(\mathrm{F}_{6}\right), 20 / 10(\%)\left(\mathrm{F}_{7}\right)$ and $20 / 15(\%)\left(\mathrm{F}_{8}\right)$ showed the effect of PF-68 concentration on viscosity. The four formulations were liquid at 4 and 25 ${ }^{\circ} \mathrm{C}$. At $4{ }^{\circ} \mathrm{C}$, the four formulations did not show any notable change in viscosity. At 25 ${ }^{\circ} \mathrm{C}$, formulation $15 / 20(\%)\left(\mathrm{F}_{6}\right)$ showed 1.8 -fold higher viscosity compared to $15 / 15(\%)$ $\left(\mathrm{F}_{5}\right)$, but formulation $20 / 15(\%)\left(\mathrm{F}_{8}\right)$ showed 1.3-fold higher viscosity compared to formulation $20 / 10(\%)\left(\mathrm{F}_{7}\right)$ at $25^{\circ} \mathrm{C}$. At $37{ }^{\circ} \mathrm{C}$, formulations $15 / 20(\%)\left(\mathrm{F}_{6}\right)$ and $20 / 15(\%)$ $\left(\mathrm{F}_{8}\right)$ showed 14.4- and 1.1-fold higher viscosity than the other formulations, respectively. This is attributed to the fact that the thickening power of pluronics in water increased with the hydrophobic molecular mass and the ethylene oxide/propylene oxide ratios (17).

\section{Mucoadhesive force determination}

Mucoadhesive force is an important and crucial physicochemical parameter for in situ forming vaginal gels since it prevents the formulation from rapid drainage and hence prolongs its residence time. Results of the determination of mucoadhesive forces of all the formulations are collected in Table III. This table shows that the prepared MTZ in situ gelling formulations with PF-127 possessed satisfactory adhesive properties. Increasing the mucoadhesive polymer concentration significantly increased the mucoadhesive force. Similar results were previously reported (18). The mucoadhesion rank order for PF-127 formulations was $20<25<30 \%$.

Addition of PF-68, which is a homologene of PF-127, enhanced the bioadhesive force, since the pluronic with a hydrophilic oxide group could bind to oligosaccharide chains. The higher the concentration of PF-68, the greater the bioadhesive force of pluronic gels.

\section{In vitro release of MTZ from in situ gelling formulations}

Fig. 1 shows the cumulative amount of MTZ released vs. time profiles for various drug-containing polymer solutions and the drug solution (control). All the polymer solutions and the control contained $0.8 \%(\mathrm{~m} / \mathrm{m}) \mathrm{MTZ}$. For the drug solution, more than 90 $\%$ of MTZ was released after $1.5 \mathrm{~h}$.

To study the effect of PF-127 concentration on drug release, the release of MTZ from different PF-127 concentrations was investigated. Drug concentration $(0.8 \%, \mathrm{~m} / \mathrm{m})$ and the temperature $37 \pm 0.2{ }^{\circ} \mathrm{C}$ were kept constant, while the PF-127 concentration was varied $(20,25$ and $30 \%)$. The results show that as the concentration of PF-127 increased from 20 to $30 \%$, the amount of drug released decreased. This indicates that the structure of the gel functioned as an increasingly resistant barrier to drug release as the concentration of PF-127 increased. Such enhanced resistance may be due to the reduction in the number and dimension of water channels and to the increase in the number and size of micelles within the gel structure. Shorter intermicellar distance leads to a larger number of cross-links between neighboring micelles, leading to higher viscosity and lower rate of drug release (19). This assumption may be potentiated by the rheology study. From the rheological study, it was observed that there is an inversely proportional relationship between MTZ viscosity and release rate. 
E. S. A. Ibrahim et al:: Development and characterization of thermosensitive pluronic-based metronidazole in situ gelling formulations for vaginal application, Acta Pharm. 62 (2012) 59-70.

\section{Effect of PF-68 on the release rate}

To study the effect of PF-68 on the release rate of MTZ from the pluronic-based in situ gelling formulations, a release test was performed using the formulations composed of a constant concentration of PF-127 $(15$ or $20 \%, \mathrm{~m} / \mathrm{m})$ and variable concentrations of PF-68. PF-68 showed little effect on the release rate of MTZ from in situ gelling formulations. As shown in Fig. 1, the addition of $20 \%$ PF-68 to $15 \%$ PF-127 $\left(\mathrm{F}_{6}\right)$ resulted in a slight decrease in the release rate compared to $15 \%$ PF- $68\left(\mathrm{~F}_{5}\right)$. In case of $20 \%$ PF-127, the addition of $10 \%\left(\mathrm{~F}_{7}\right)$ and $15 \%$ PF-68 $\left(\mathrm{F}_{8}\right)$ showed a very low reduction in the release rate. This slight decrease in the release rate may be attributed to the increase in viscosity.

The formula suggested for clinical study was $\mathrm{F}_{7}$ based on $T_{\text {gel }}$, which was considered an important parameter. The formulations with suitable $T_{\text {gel }}$ were $\mathrm{F}_{5}, \mathrm{~F}_{6}, \mathrm{~F}_{7}$, and $F_{8}$. The rank order for drug release was $F_{5}>F_{6}>F_{7} \geq F_{8}$. Thus, the final choice between $\mathrm{F}_{7}$ and $\mathrm{F}_{8}$ depended on the viscosity, mucoadhesion and the total concentration of the two pluronics. Table IV shows that the difference between $\mathrm{F}_{7}$ and $\mathrm{F}_{8}$ regarding viscosity and mucoadhesion was very small. Either of the two formulations could be used, so the formula that contained smaller concentration of pluronic (20/10 \%) was recommended $\left(\mathrm{F}_{7}\right) . \mathrm{F}_{7}$ was easier to be prepared than $\mathrm{F}_{8}$.

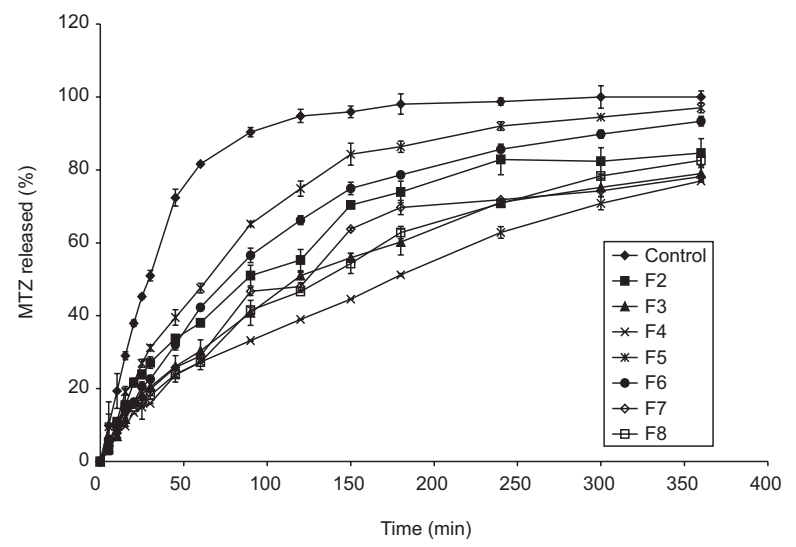

Fig. 1. Effect of concentrations of PF-127 alone and PF-127/PF-68 combinations on the release profile of MTZ from in situ gelling formulations (SEM bars, $n=3$ ).

Table IV. Viscosity and mucoadhesion difference between $F_{7}, F_{8}$ and Tricho ${ }^{\circledR}$ gel

\begin{tabular}{ccccc}
\hline \multirow{2}{*}{ Formula code } & \multicolumn{3}{c}{ Viscosity (mPa s) } & $\begin{array}{c}\text { Bioadhesive force } \\
\times 10^{2}\left(\mathrm{~N} \mathrm{~cm}^{-2}\right)^{\mathrm{a}}\end{array}$ \\
\cline { 2 - 4 } & $4{ }^{\circ} \mathrm{C}$ & $25^{\circ} \mathrm{C}$ & $37^{\circ} \mathrm{C}$ & $21.2 \pm 1.4$ \\
$\mathrm{~F}_{7}$ & 306 & 932 & $199.6 \times 10^{3}$ & $23.9 \pm 0.4$ \\
$\mathrm{~F}_{8}$ & 422 & 1177.7 & $222.4 \times 10^{3}$ & $11.3 \pm 3.4$ \\
\hline Tricho $^{\circledR}$ gel & $153.5 \times 10^{3}$ & $156 \times 10^{3}$ & $156.1 \times 10^{3}$ & \\
\hline
\end{tabular}

a Mean \pm SD, $n=3$. 
E. S. A. Ibrahim et al.: Development and characterization of thermosensitive pluronic-based metronidazole in situ gelling formulations for vaginal application, Acta Pharm. 62 (2012) 59-70.

\section{Histopathological study of vaginal tissues}

Histopathological examinations from the control group and from the treated group (after using formulation $\mathrm{F}_{7}$ ) revealed normal histology of the vagina and cervix (Fig. 2). It was reported that thermosensitive gel vehicles, which were composed mainly of pluronics (PF-127 and PF-68), did not influence the viability of the cells and did not alter the morphology of vaginal tissues, i.e., there was no visible sign of inflammation or necrosis (1).

Comparison of MTZ release from the selected in situ gelling formula $\left(F_{7}\right)$ and the marketed gel (Tricho ${ }^{\circledR}$ gel)

We compared our formula to the marketed formulation already in use regarding sustained release, viscosity and mucoadhesion as the basis for our clinical study.

It was found that the release from MTZ in situ gelling formulation $\mathrm{F}_{7}$ was slower than that from the marketed gel (Tricho ${ }^{\circledR}$ gel). After $6 \mathrm{~h}$, the percent drug released form Tricho ${ }^{\circledR}$ gel was $91 \%$, while the percentage released from $\mathrm{F}_{7}$ was $76 \%$ (Fig. 3a). Fig. 3b shows that the drug was completely released from Tricho ${ }^{\circledR}$ gel after $12 \mathrm{~h}$, while $90 \%$ MTZ was released from $\mathrm{F}_{7}$ after the same period. These in vitro results suggest that plu-


Fig. 2. a) Vagina of control rabbits showing normal epithelial lining, b) cervix of control rabbits showing normal epithelial lining, $c$ ) vagina of metronidazole treated rabbits ( $F_{7}$ formulation) showing normal epithelial lining, $\mathrm{d}$ ) cervix of metronidazole ( $\mathrm{F}_{7}$ formulation) treated rabbits showing normal epithelial lining (magnification 40x). 
ronic formulations might serve as a rate-controlling barrier and can be useful as a vehicle for sustained release preparations of MTZ.

The differences between formulation $\mathrm{F}_{7}$ and Tricho ${ }^{\circledR}$ gel in viscosity and mucoadhesion are summarized in Table IV. Viscosity of Tricho ${ }^{\circledR}$ gel did not change with temperature increase. In contrast to Tricho ${ }^{\circledR}$ gel, the free flowing property of formula $\mathrm{F}_{7}$ would enable the patient to apply the required dose accurately and would result in good spreading and coating of the vagina. At $37^{\circ} \mathrm{C}$, the viscosity of $\mathrm{F}_{7}$ was higher than that of Tricho ${ }^{\circledR}$ gel. Table IV shows that the mucoadhesion expressed as detachment force of formula $\mathrm{F}_{7}$ and Tricho ${ }^{\circledR}$ gel were 0.2116 and $0.1133 \mathrm{~N} \mathrm{~cm}^{-2}$, respectively. Based on these results, it is expected that formula $\mathrm{F}_{7}$ will be retained on vaginal mucosal tissue for a longer period than the Tricho ${ }^{\circledR}$ gel.

Clinical evaluation of formula $\mathrm{F}_{7}$ in comparison with the marketed preparation (Tricho ${ }^{\circledR}$ gel) in patients with bacterial vaginosis (20) showed that the cure rate after one week of treatment was $85 \%$ in the in situ gel $\mathrm{F}_{7}$ group and $71 \%$ in the conventional vaginal gel group (Tricho ${ }^{\circledR}$ gel), while after 4 weeks, the cure rate showed a significant difference in the in situ gel group compared to the conventional vaginal gel group (80 versus $47 \%$, respectively, $p=0.034$ ). This shows that the in situ MTZ vaginal gel $\mathrm{F}_{7}$ is more effective than the conventional vaginal gel product for sustained cure of bacterial vaginosis.
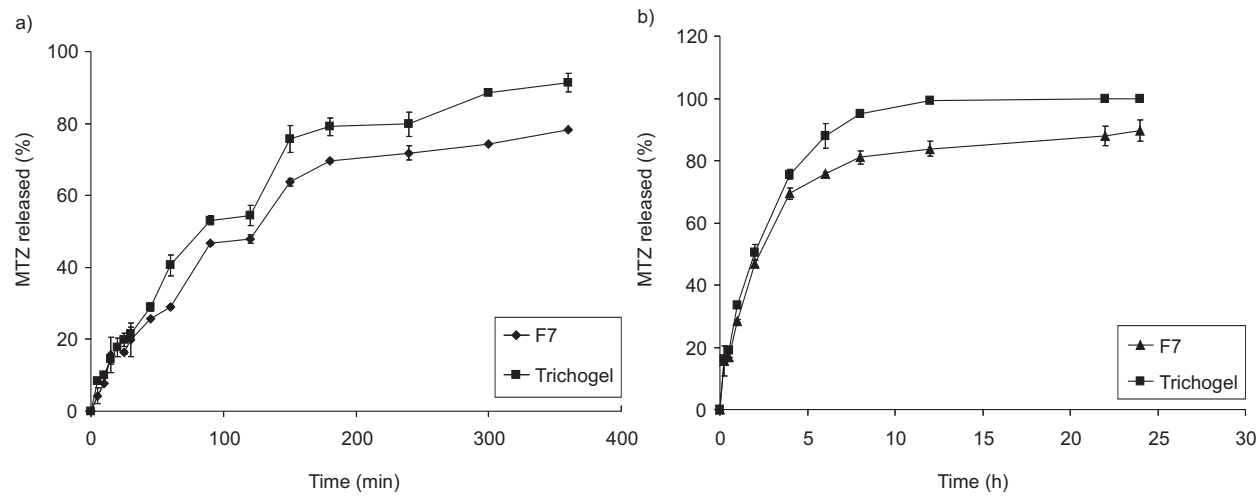

Fig. 3. Comparison of MTZ release from formulation $\mathrm{F}_{7}$ and the marketed preparation (Tricho ${ }^{\circledR}$ gel) after: a) $6 \mathrm{~h}$ and b) $24 \mathrm{~h}$ (SEM bars, $n=3$ ).

\section{CONCLUSIONS}

The in situ gelling liquids are considered a more convenient formulation for topical application into the vagina. Formula $\mathrm{F}_{7}$ was the most suitable of pluronic formulations. It showed appropriate viscosity, mucoadhesion, delayed release and $T_{\text {gel }}$ within the suitable range. From the release and mucoadhesion studies, it was found that the in situ gel formula will be retained in the vagina for a longer period than Tricho ${ }^{\circledR}$ gel. Histopatho- 
E. S. A. Ibrahim et al.: Development and characterization of thermosensitive pluronic-based metronidazole in situ gelling formulations for vaginal application, Acta Pharm. 62 (2012) 59-70.

logical examination of vaginal and cervical sections from the control and MTZ treated groups revealed normal histology. Hence, the use of this formulation is expected to make the treatment more effective as it gives good spreading and coating properties of the vagina, which was confirmed by the clinical study conducted later on.

\section{REFERENCES}

1. J. Y. Chang, Y.-K. Oh, H. G. Choi, Y. B. Kim and C.-K. Kim, Rheological evaluation of thermosensitive and mucoadhesive vaginal gels in physiological conditions, Int. J. Pharm. 241 (2002) 155-163; DOI: 10.1016/S0378-5173(02)00232-6.

2. Y. Qiu and K. Park, Environment-sensitive hydrogels for drug delivery, Adv. Drug Deliv. Rev. 53 (2001) 321-339; DOI: 10.1016/S0169-409X(01)00203-4.

3. C. K. Mauck, D. Katz, E. P. Sandefer, M. D. Nasution, M. Henderson, G. A. Digenis, I. Su, R. Page and K. Barnhart, Vaginal distribution of Replens and K-Y jelly using three imaging techniques, Contraception 77 (2008) 195-204; DOI: 10.1016/j.contraception.2007.11.016.

4. I. R. Schmolka, Artificial skin. I. Preparation and properties of pluronic F-127 gels for the treatment of burns, J. Biomed. Mater. Res. 6 (1972) 571-582; DOI: 10.1002/jbm.820060609.

5. H. G. Choi, J. H. Jung, J. M. Ryu, S. J. Yoon, Y. K. Oh and C. K. Kim, Development of in situ-gelling and mucoadhesive acetaminophen liquid suppository, Int. J. Pharm. 165 (1998) 33-44; DOI: 10.1016/S0378-5173(97)00386-4.

6. A. A. Koffi, F. Agnely, G. Ponchel and J. L. Grossiord, Modulation of the rheological and mucoadhesive properties of thermosensitive poloxamer based hydrogels intended for the rectal administration of quinine, Eur. J. Pharm. Sci. 27 (2006) 328-335; DOI: 10.1016/j.ejps.2005.11.001.

7. H. S. Ch'ng, H. Park, P. Kelly and J. R. Robinson, Bioadhesive polymers as platforms for oral controlled drug delivery. II. Synthesis and evaluation of some swelling water insoluble bioadhesive polymers, J. Pharm. Sci. 74 (1985) 339-405.

8. D. Woolfson, M. L. Umrethia, V. L. Kett and R. K. Malcolm, Freeze-dried, mucoadhesive system for vaginal delivery of the HIV microbicide, dapivirine: Optimisation by an artificial neural network, Int. J. Pharm. 388 (2010); DOI: 10.1016/j.ijpharm.2009.12.042.

9. A. D. Woolfson, M. L. Umrethia, V. L. Kett and R. K. Malcolm, Freeze-dried, mucoadhesive system for vaginal delivery of the HIV microbicide, dapivirine: Optimisation by an artificial neural network, Int. J. Pharm. 388 (2010)136.143; DOI: 10.1016/j.ijpharm.2009.12.042.

10. J. Y. Chang, Y.-K. Oh, H. S. Kong, E. J. Kim, D. D. Jang, K. T. Nam and C.-K. Kin, Prolonged antifungal effects of clotrimazole-containing mucoadhesive thermosensitive gels on vaginitis, J. Control Release 82 (2002) 39-50; DOI: 10.1016/S0168-3659(02)00086-X.

11. E. Y. Kim, Z. G. Gao, J. S. Park, H. Li and K. Han, rhEGF/HP- $\beta-C D$ complex in poloxamer gel for ophthalmic delivery, Int. J. Pharm. 233 (2002) 159-167; DOI: 10.1016/S0378-5173(01)00933-4.

12. A. L. Rashad, W. L. Toffler, N. Wolf, K. Thoraburg, E. P. Kirk, G. Ellis and W. E. Whitehead, Vaginal P02 in healthy women and in women infected with Trichomoniasis vaginalis: Potential implications for metronidazole therapy, Am. J. Obestet. Gynecol. 166 (1992) 620-624.

13. K. Edsman, J. Carlfors and R. Petersson, Rheological evaluation of poloxamer as an in situ gel for ophthalmic use, Eur. J. Pharm. Sci. 6 (1998) 105-112; DOI: 10.1016/S0928-0987(97)00075-4.

14. H. Qi, L. Li, C. Huang, W. Li and C. Wu, Optimization and physicochemical characterization of thermosensitive poloxamer gel containing puerarin for ophthalmic use, Chem. Pharm. Bull. 54 (2006) 1500-1507; DOI 10.1248/cpb.54.1500.

15. A. Cabana, A. Ait-Kadi and J. Juhasz, Study of the gelation process of polyethylene oxide-polypropylene oxide-polyethylene oxide copolymer (poloxamer 407) aqueous solutions, J. Colloid Interface Sci. 190 (1997) 307-312; DOI: 10.1006/jcis.1997.4880. 
E. S. A. Ibrahim et al:: Development and characterization of thermosensitive pluronic-based metronidazole in situ gelling formulations for vaginal application, Acta Pharm. 62 (2012) 59-70.

16. N. Jain, V. Aswal, P. Goyal and P. Bahadur, Micellar structure of an ethylene oxide-propylene oxide block copolymer: a small-angle neutron scattering study, J. Phys. Chem. 102 (1998) 8452-8460; DOI: $10.1021 /$ jp9825680.

17. I. R. Schmolka, A review of block polymer surfactants, J. Am. Oil Chem. Soc. 54 (1977) 110-116; DOI: $10.1007 /$ BF02894385.

18. C. Charrueau, C. Tuleu, V. Astre, J.-L. Grossiord and J.-L. Chaumeil, Poloxamer 407 as a thermogelling and adhesive polymer for rectal administration of short-chain fatty acids, Drug Dev. Ind. Pharm. 27 (2001) 351-357; DOI: 10.1081/DDC-100103735.

19. P. Alexandridis and T. A. Hatton, Poly(ethylene oxide)-poly(propylene oxide)-poly(ethylene oxide) block copolymer surfactants in aqueous solutions and at interfaces: thermodynamic, structure, dynamic and modeling, Colloid Surface A 96 (1995) 1-46; DOI: 10.1016/0927-7757(94)03028-X.

20. O. M. Shaaban, G. N. Fetih, N. H. Abdellah, S. Ismail, M. A. Ibrahim and S. A. Ibrahim, A pilot randomized trial for treatment of bacterial vaginosis using in-situ forming metronidazole vaginal gel, J. Obstet. Gynecol. Res. 37 (2011) 874-881; DOI: 10.1111/j.1447-0756.2010.01457.x.

\section{$S A \check{Z} E T A K$}

\section{Razvoj i karakterizacija in situ gelirajućih pripravaka metronidazola na bazi pluronika za vaginalnu primjenu}

EL-SAYED ALI IBRAHIM, SAYED ISMAIL, GIHAN FETIH, OMAR SHAABAN, KHALED HASSANEIN i NOURA HASSAN ABDELLAH

Cilj rada bio je razviti pripravke metronidazola (MTZ) za liječenje bakterijske vaginoze koji imaju sposobnost geliranja in situ, produljeno vrijeme zadržavanja na mjestu primjene, kontrolirano oslobađanje ljekovite tvari, povećanu učinkovitost te smanjiti ponovnu pojavu vaginoze i povećati suradljivost pacijenta. Pripravci koji geliraju in situ pripravljeni su koristeći različite koncentracije pluronika F-127 (PF-127), samog ili u kombinaciji s pluronikom F-68 (PF-68). Ispitivana je temperatura geliranja $\left(T_{\text {gel }}\right)$ formulacija, in vitro oslobađanje ljekovite tvari, reološka svojstva, mukoadhezijska svojstva te kako ih podnaša vaginalna sluznica u slojevima tkiva. Uočeno je da se s povećanjem koncentracije PF-127 snižava $T_{\text {gel }}$. Dodatkom različitih količina PF-68 dobiveni su pripravci s rasponom $T_{\text {gel }}$ od 25 do $37^{\circ} \mathrm{C}$. S povećanjem koncentracije pluronika smanjilo se oslobađanje ljekovite tvari in vitro, a povećala se viskoznost i mukoadhezivnost. Histopatološka ispitivanja na zečicama ispitivane i kontrolne skupine dala su normalni histološki nalaz njihovih vagina i cerviksa. Na temelju in vitro evaluacije, formulacija s PF-127/ PF-68 $(20 / 10 \%, m / m)$ izabrana je za daljnja klinička ispitivanja.

Ključne riječi: metronidazol, in situ geliranje, mukoadhezija, pluronici

Department of Pharmaceutics, Faculty of Pharmacy, Assiut University, Egypt

Department of Obstetrics and Gynecology, Faculty of Medicine, Assiut University, Egypt

Department of Pathology and Clinical Pathology, Faculty of Veterinary Medicine, Assiut University, Egypt 